\title{
Traumatic Retinal Angiopathy - Associated with Wearing of Car Seat Belts
}

\author{
D. B. ARCHER, O. E. EARLEY, A. B. PAGE, P. B. JOHNSTON \\ Belfast
}

\begin{abstract}
Summary
Three patients who were involved in road traffic accidents and sustained seat belt related injuries developed a retinal angiopathy characterised by retinal haemorrhage, oedema and focal ischaemia. Significant unilateral visual loss $(2 / 60-6 / 18)$ was reported $1-48$ hours following injury and central or paracentral annular scotomata were present. Although there was good recovery of visual acuity all patients had permanent scotomata, colour vision defects and loss of contrast sensitivity. Residual retinal microvascular and haemodynamic changes were noted on fluorescein angiography and the visually evoked responses were uniformly depressed. The structural and functional alterations in the retina of patients who have sustained seat belt injuries have important medico-legal implications.
\end{abstract}

There is now compelling evidence that the use of vehicle seat belts significantly reduces fatalities and serious injuries following road traffic accidents. ${ }^{1}$ Several recent studies also report a substantial decline in the number of perforating eye injuries, in some instances by as much as $70 \%$, in countries where seat belt legislation has been introduced and compliance is high.,3,4 Although seat belts have undoubted advantages in preventing severe injuries due to violent and precipitate movements of driver or passengers inside the vehicle, they also concentrate considerable mechanical force on the chest and abdomen following acute acceleration or deceleration accidents. Fractured ribs and sternum, damage to internal organs and rupture of gut, have all been attributed to severe compression by car safety belts..$^{1,5,6}$ There has also been a reported increase in the incidence of cervical sprains since the introduction of seat belts in some regions. ${ }^{1}$

Less commonly, individuals wearing seat belts in road traffic accidents have developed a severe retinal vasculopathy characterised by retinal haemorrhages, focal inner retinal ischaemia and often profound loss of vision..$^{7,8,9}$ The degree of visual recovery following this traumatic retinal angiopathy is highly variable and often unpredictable and few studies have evaluated the long term visual effects of such injuries. This paper reports the ophthalmic findings in three patients who had visual symptoms and retinal vascular changes following road traffic accidents where seat belts caused either chest or neck injuries. The natural course of this unusual but characteristic retinopathy is documented with particular emphasis on the long term sequelae which often have imporant medicolegal implications.

\section{Materials and Methods}

Three patients were studied who were involved in road traffic accidents and had chest or neck injuries attributable to the wearing of seat belts. All had visual complaints relating to the time of the accident and evidence of retinal vascular disease. Each patient had a detailed evaluation of vis- 
ual functions including Tubinger visual fields, colour vision (Farnsworth Munsell 100 hue test) and contrast sensitivity analysis (Arden Gratings). The fundi were documented photographically and fluorescein angiography performed. Each patient had electrophysiological assessment (electroretinogram, patterned visually evoked response, pseudorandom binary stimulus visually evoked response ${ }^{10}$ ) and measurement of ocular pulse (Alcon Pneumotonography). The data is summarised in Tables I and II.

\section{Case 1 (SS)}

A 46-year-old female was involved in a road traffic accident while wearing a seat belt, on 6 July 1984 . She was sitting in a stationary car which was struck on the front passenger side. She had bruising of the thorax in the distribution of the seat belt and severe chest pain. A subsequent $\mathrm{x}$-ray revealed a small undisplaced crack fracture of the sternum.
The patient was not unconscious and sustained no direct ocular trauma or other significant injuries. Within one hour of the accident the patient complained of poor vision in her right eye and acuity was documented as 6/18 right and 6/6 left. Vision was previously good and equal in both eyes. Ophthalmoscopy confirmed the presence of multiple peripapillary cotton wool spots, scattered intraretinal haemorrhages at the posterior pole of the right eye and a subhyaloid haemorrhage below the infero-temporal vascular arcades. The left fundus was normal.

The retinopathy slowly resolved over the ensuing months, however, at 3 months post-injury cotton wool spots were still identifiable (Fig. 1); and fluorescein angiography confirmed the presence of focal areas of inner retinal ischaemia, scattered intraretinal microvascular abnormalities and a sluggish retinal circulation. By 10 months there was no evidence of retinopathy although there was temporal pallor of the right optic disc and attenuation of retinal arterioles and venules. Red-free

Table I. Retinal vasculopathy and seat belt injuries summary of patient data

\begin{tabular}{|c|c|c|c|c|c|c|c|c|c|}
\hline Case No. & Age & $\begin{array}{l}\text { Nature of } \\
\text { accident }\end{array}$ & $\begin{array}{l}\text { Injuries } \\
\text { sustained }\end{array}$ & $\begin{array}{l}\text { Ophthalmic } \\
\text { complaints }\end{array}$ & $\begin{array}{l}\text { Initial } \\
\text { vision }\end{array}$ & $\begin{array}{l}\text { Final } \\
\text { vision }\end{array}$ & $\begin{array}{l}\text { Initial } \\
\text { fundus } \\
\text { changes }\end{array}$ & $\begin{array}{l}\text { Final Fundus } \\
\text { changes }\end{array}$ & $\begin{array}{l}\text { Final } \\
\text { angiographic } \\
\text { features }\end{array}$ \\
\hline $1(\mathrm{SS})$ & 46 & $\begin{array}{l}\text { Front seat } \\
\text { passenger in } \\
\text { stationary } \\
\text { car, head on } \\
\text { collision } \\
\text { passenger } \\
\text { side }\end{array}$ & $\begin{array}{l}\text { Bruising } \\
\text { chest } \\
\text { Fracture } \\
\text { sternum }\end{array}$ & $\begin{array}{l}\text { Poor vision } \\
\text { R eye, noted } \\
\text { one hour } \\
\text { following } \\
\text { accident }\end{array}$ & $6 / 186 / 6$ & $6 / 126 / 6$ & $\begin{array}{l}\text { Peripapillary } \\
\text { cotton wool } \\
\text { spots intra- } \\
\text { retinal and } \\
\text { preretinal } \\
\text { haemorrhage }\end{array}$ & $\begin{array}{l}\text { Optic disc } \\
\text { pallor } \\
\text { Attenuated } \\
\text { vessels }\end{array}$ & $\begin{array}{l}\text { Prolonged } \\
\text { retinal } \\
\text { circulation } \\
\text { time. Focal } \\
\text { inner retinal } \\
\text { ischaemia } \\
\text { intraretinal } \\
\text { microvas. } \\
\text { abnormalities }\end{array}$ \\
\hline $2(\mathrm{DL})$ & 27 & $\begin{array}{l}\text { Front seat } \\
\text { passenger, } \\
\text { head on } \\
\text { collision } \\
(30 \mathrm{MPH})\end{array}$ & $\begin{array}{l}\text { Bruising } \\
\text { neck } \\
\text { Fracture } \\
\text { sternum } \\
\text { Difficulty } \\
\text { breathing }\end{array}$ & $\begin{array}{l}\text { Blurring } \mathrm{R} \\
\text { vision with } \\
\text { central blind } \\
\text { spot noted } 22 \\
\text { hours post- } \\
\text { accident }\end{array}$ & $6 / 606 / 6$ & $6 / 66 / 5$ & $\begin{array}{l}\text { Macular } \\
\text { haemorrhages } \\
\text { oedema }\end{array}$ & $\begin{array}{l}\text { Temporal } \\
\text { pallor } \\
\text { optic disc }\end{array}$ & $\begin{array}{l}\text { Gross } \\
\text { retinal } \\
\text { arterial } \\
\text { stasis - slow } \\
\text { perfusion } \\
\text { micro- } \\
\text { vasculature }\end{array}$ \\
\hline $3(\mathrm{KH})$ & 21 & $\begin{array}{l}\text { Frontseat } \\
\text { passenger. } \\
\text { Head on } \\
\text { collision }\end{array}$ & $\begin{array}{l}\text { Injury neck } \\
\text { and face. } \\
\text { No frac- } \\
\text { tures. } \\
\text { Cervical } \\
\text { support } \\
\text { prescribed }\end{array}$ & $\begin{array}{l}\text { Blurring L } \\
\text { vision noted } \\
48 \text { hours } \\
\text { post accident }\end{array}$ & $6 / 62 / 60$ & $6 / 66 / 9$ & $\begin{array}{l}\text { Peri- } \\
\text { papillary } \\
\text { cotton wool } \\
\text { spots intra- } \\
\text { retinal } \\
\text { haemorrhages } \\
\text { macular } \\
\text { oedema }\end{array}$ & $\begin{array}{l}\text { Optic } \\
\text { atrophy, } \\
\text { fine } \\
\text { retinal } \\
\text { pigment } \\
\text { epithelial } \\
\text { changes } \\
\text { posterior } \\
\text { fundus }\end{array}$ & $\begin{array}{l}\text { Attenuated } \\
\text { and slowly } \\
\text { perfused } \\
\text { retinal micro- } \\
\text { vasculature. } \\
\text { Optic disc } \\
\text { hypo- } \\
\text { fluorescent. }\end{array}$ \\
\hline
\end{tabular}


photographs showed nerve fibre bundle lesions at the posterior pole of the right eye, and fluorescein angiography identified residual capillary abnormalities and a prolonged retinal circulation time.

At $1 \frac{1}{2}$ years post-accident visual acuity measured $6 / 12$ right and 6/6 left and visual fields demonstrated a right paracentral annular scotoma (Fig. 2a). Colour vision (Farnsworth Munsell 100 hue test) revealed a generalised loss of colour discrimination (738 errors) (Fig. 2b). The electroretinogram was normal, but the patterned visually evoked response was delayed and of reduced

Table II. Retinal vasculopathy and seat belt injuries. Special investigations: final results

\begin{tabular}{|c|c|c|c|c|c|c|}
\hline $\begin{array}{l}\text { Visual } \\
\text { fields }\end{array}$ & Colour vision & Electrophysiology & $\begin{array}{l}\text { Contrast } \\
\text { sensitivity }\end{array}$ & $\begin{array}{l}\text { Ocular } \\
\text { pulse }\end{array}$ & $\begin{array}{l}\text { Time } \\
\text { follow up }\end{array}$ & $\begin{array}{l}\text { Final } \\
\text { complaints }\end{array}$ \\
\hline $\begin{array}{l}1(\mathrm{SS}) \\
\text { Paracentral } \\
\text { annular } \\
\text { scotoma }\end{array}$ & $\begin{array}{l}\text { Generalised loss of } \\
\text { colour discrimination } \\
\text { ( } 738 \text { errors) }\end{array}$ & $\begin{array}{l}\text { Pattern VER - R } \\
\text { reduced amplitude } \\
\text { increased latency } \\
\text { PRBS - VER - R } \\
\text { increased latency } \\
\text { diminished } \\
\text { amplitude }\end{array}$ & Abnormal R eye & $\begin{array}{l}\text { Normal and } \\
\text { equal L \& R }\end{array}$ & $1 \frac{1}{2}$ years & $\begin{array}{l}\text { Impaired R } \\
\text { vision and } \\
\text { stereopsis }\end{array}$ \\
\hline $\begin{array}{l}2(\mathrm{DL}) \\
\text { Paracentral } \\
\text { annular } \\
\text { scotoma }\end{array}$ & $\begin{array}{l}\text { Red/green defect } \\
\text { (156 errors) }\end{array}$ & $\begin{array}{l}\text { Pattern VER and } \\
\text { PRBS VER subnormal } \\
\text { and delayed - } \mathrm{R}\end{array}$ & Abnormal R & $\begin{array}{l}\text { Normal and } \\
\text { equal R \& L }\end{array}$ & 1 year & $\begin{array}{l}\text { Impaired } \\
\text { quality vision } \\
\text { R eye }\end{array}$ \\
\hline $\begin{array}{l}3(\mathrm{KH}) \\
\text { Paracentral } \\
\text { scotoma }\end{array}$ & $\begin{array}{l}\text { gross red/green } \\
\text { defect } \\
\text { (386 errors) }\end{array}$ & $\begin{array}{l}\text { Pattern VER - L } \\
\text { grossly abnormal } \\
\text { PRBS VER }\end{array}$ & $\begin{array}{l}\text { Grossly } \\
\text { abnormal-L }\end{array}$ & $\begin{array}{l}\text { Normal and } \\
\text { equal R \& L }\end{array}$ & $81 / 2$ years & $\begin{array}{l}\text { Impaired vision } \\
\text { L eye }\end{array}$ \\
\hline
\end{tabular}

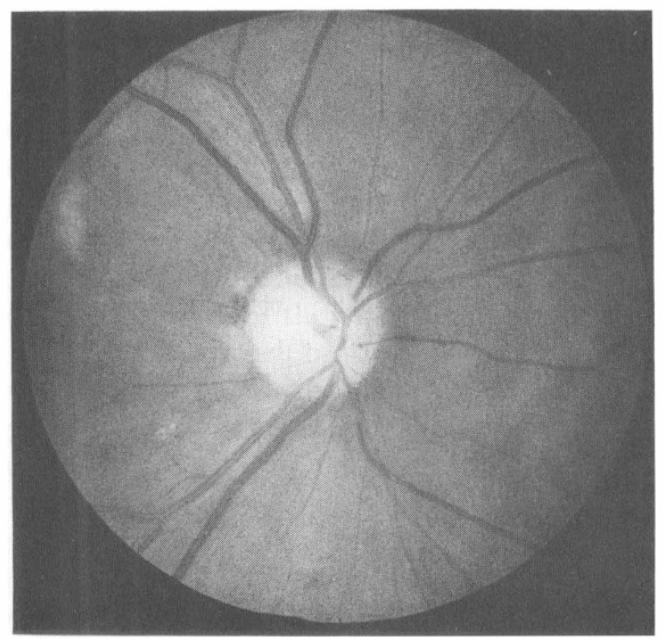

Fig. 1a. Case 1 (SS). Right posterior fundus 2 months following road traffic accident. Residual cotton wool spots are present about the posterior pole of the eye particularly superior and nasal to the right macula.

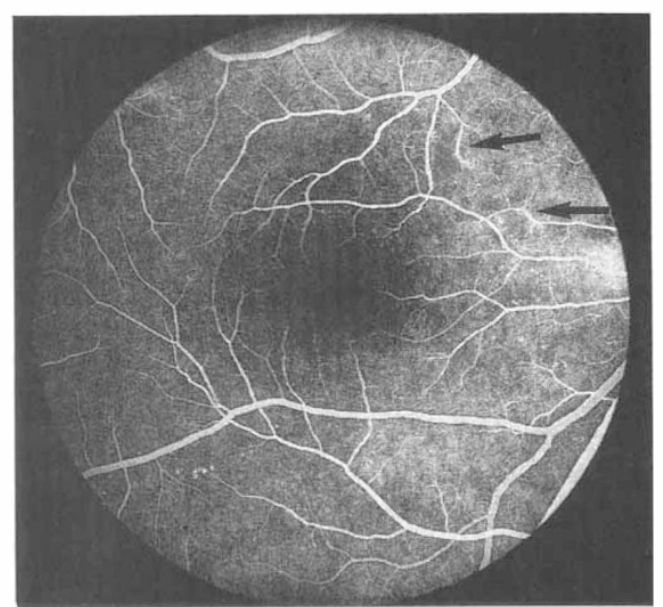

Fig. 1b. Case 1 (SS). Venous phase fluorescein angiogram right fundus $31 / 2$ months post trauma. Several focal areas of inner retinal ischaemia are still present and a number of intraretinal microvascular abnormalities are identifiable (arrows). 
amplitude on the right side, and the patterned reversal binary stimulus, visually evoked response was also subnormal and delayed on this side. All left sided electrophysiological responses were normal and the ocular pulse was normal on each side.

Contrast sensitivity tests confirmed a significant difference between the two eyes. At final review the patient complained that vision was still impaired in the right eye and that she experienced some difficulty making judgments of depth and coping with tasks requiring stereopsis.

\section{Case 2 (DL)}

This 27-year-old female was a front seat passenger in a head-on collision with another car, at an estimated speed of $30 \mathrm{mph}$. The patient experienced severe mid-sternal pain and had difficulty breathing and discomfort on coughing, for several hours. There was bruising of the chest corresponding to the configuration of the seat belt. Neck movements were painful and restricted. An undisplaced fracture of sternum was noted on $\mathrm{x}$-ray; however, radiological investigations of the cervical vertebrae, head, chest and orbit were negative. Serum amylase was normal.

Twenty-two hours after the injury the patient noted that her right vision was blurred and described the presence of a central blind spot in this eye. Visual acuity measured $6 / 60$ right and $6 / 6$ left and a central scotoma was noted on the right side. There were intraretinal haemorrhages at the right posterior fundus and macular oedema. Fluorescein angiography demonstrated a striking abnormality of retinal arterial filling and impaired

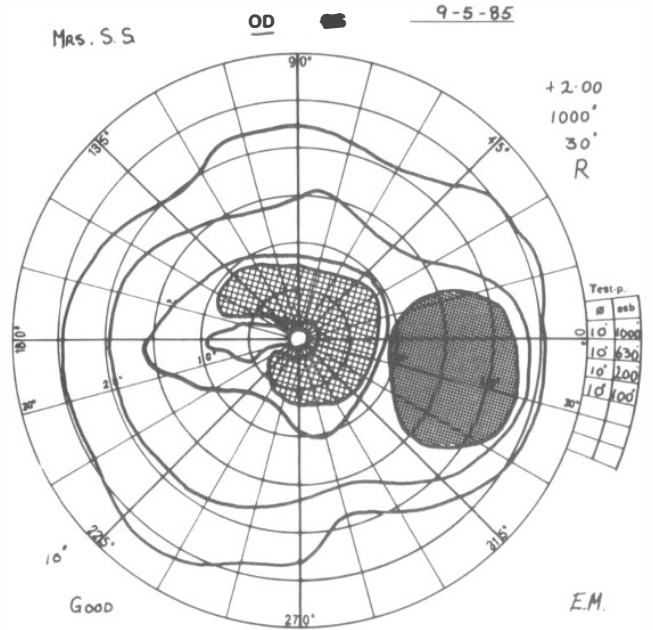

Fig. 2a. Case 1 (SS). Right central visual field 18 months post accident demonstrates a paracentral annular scotoma. perfusion of the retinal microvasculature at the posterior fundus (Figs. 3a and b). Over a period of one year the retinopathy resolved; however, striking retardation of retinal arterial filling was still evident on fluorescein angiography (Fig. 3c). Visual acuity improved from $6 / 60$ to $6 / 6$ in the affected eye, although the patient had difficulty reading small print with this eye. A pronounced red/green colour vision defect was present in the affected eye and persisted during the year of observation. The left eye was normal.

An annular paracentral scotoma was documented 2 weeks post-trauma in the right eye, and although it decreased in size and intensity over the subsequent year it was still detectable at final examination. Contrast sensitivity assessment showed a significant and persistent difference between the two eyes. The ocular pulse was normal and equal in both eyes.

Electroretinographic recordings were normal in each eye 6 days post-trauma. However, in the right eye there was a subnormal flash visually evoked response and absent patterned visually evoked response. Over the succeeding 2 months flash and patterned visually evoked responses returned to normal, but the pseudorandom binary stimulus visually evoked response was subnormal and delayed in the right eye. An abnormality of the right pseudorandom binary stimulus visually evoked response was still present at one year postinjury.

\section{Case 3 (KM)}

A 21-year-old female was involved in a head-on

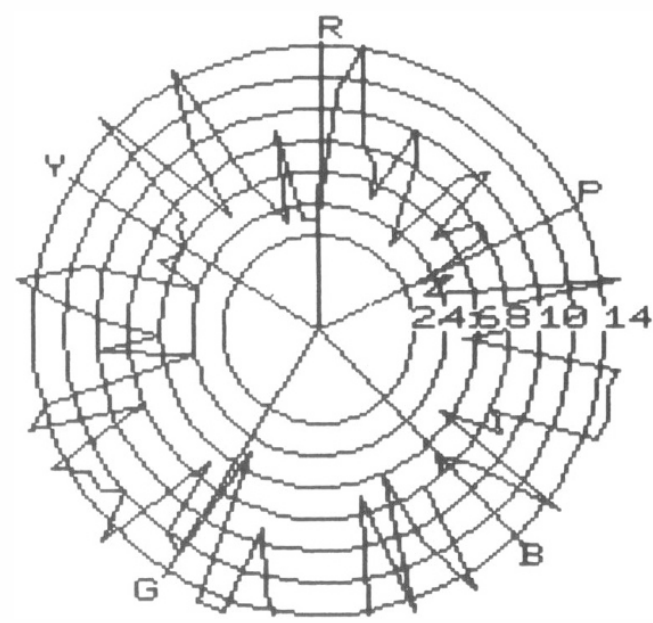

Fig. 2b. Case 1 (SS). Farnsworth-Munsell 100 hue colour vision test demonstrates a global loss of colour vision ( 738 errors). 
car collision when her head was thrown violently forward. She sustained injuries to her face, chest and neck. Despite normal x-ray of skull and cervical spine the neck was acutely painful and a cervical support collar was prescribed. The patient first

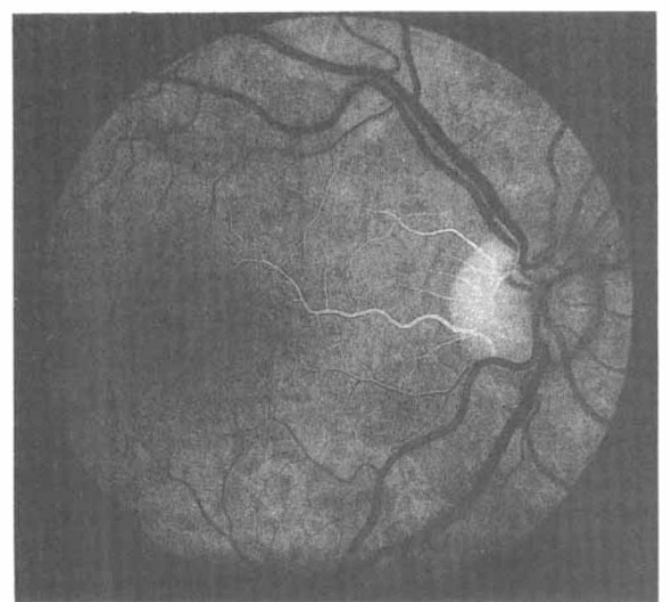

Fig. 3a. Case 2 (DL). Fluorescein angiogram right fundus 2 weeks after the road traffic accident. The angiogram taken 2.2 seconds after the first appearance of dye in the choroidal circulation demonstrates perfusion of the choroidal vasculature and a cilio-retinal system. There is no evidence of dye in the retinal arterial tree.

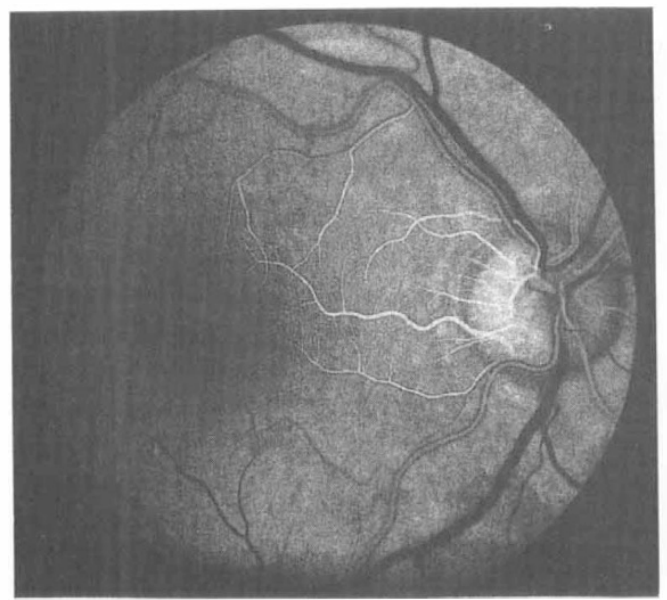

Fig. 3b. Fluorescein angiogram right fundus 2.8 seconds later than that shown Fig. 3a. There is sluggish filling of the retinal circulation as evidenced by "core filling" of the supero- and infero-temporal retinal arteries. The choroidal vaculature and temporal papillary vessels are well perfused. noticed blurred vision in the left eye 48 hours after the accident and visual acuity was recorded as $6 / 6$ right and 2/60 left at that time. Fundoscopy revealed multiple peripapillary cotton wool spots, macular oedema and scattered intraretinal haemorrhages over the posterior pole of the eye (Fig. 4a). A dense centrocaecal scotoma was present.

The retinopathy disappeared by 4 months although by this time the left optic disc was pale and atrophic. At one year post-trauma, visual acuity improved to $6 / 6$ right and 6/9 left but the patient had a left afferent pupillary defect and a residual paracentral scotoma. The left optic disc was pale and fine retinal pigment epithelial changes were observed at the posterior fundus. The right eye was normal in all respects.

At $81 / 2$ years post-accident the patient still complained that vision was poor in the left eye and acuity was recorded as $6 / 9$ part $(\mathrm{N} / 5)$. The retinal arterioles were attenuated in the left eye and the optic disc was atropic (Fig. 4b). Visual field assessment confirmed the presence of a dense paracentral scotoma in the affected eye (Fig. 5a). Colour vision was grossly abnormal with a red/green axis (Fig. 5b) and pattern visually evoked responses were of increased latency and reduced amplitude. Pseudorandom binary stimulus visually evoked responses were diminished in amplitude. All electrophysiological responses in the right eye were normal. Contrast sensitivity was strikingly reduced

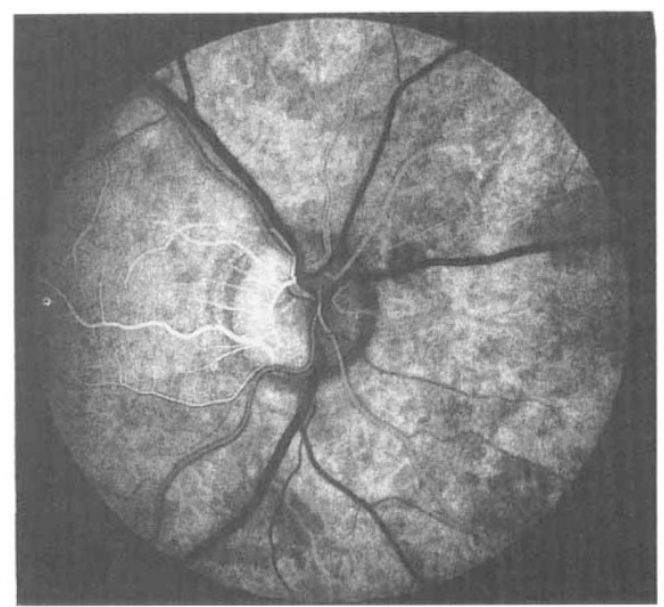

Fig. 3c. Fluorescein angiography right fundus 11 months following that demonstrated in Figs. $3 a$ and $3 b$. There is gross delay in filling of the retinal circulation. The supero-temporal and infero-temporal arteries are only partially filled but the choroidal and temporal papillary vasculatures are well perfused. 
in the affected eye although ocular pulses were equal and normal. Fluorescein angiography showed slow perfusion of the retinal microvasculature at the left posterior fundus.

\section{Discussion}

It has been recognised for some time that retinal vascular perfusion can be affected profoundly by a range of disparate mechani-

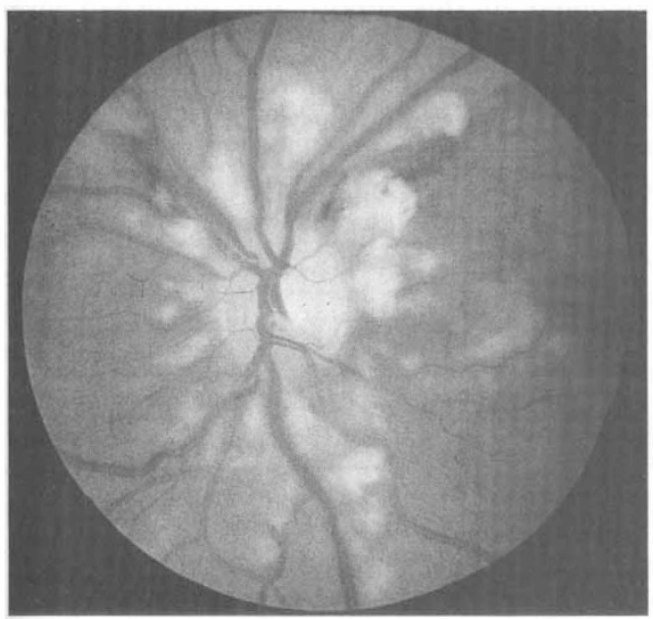

Fig. 4a. Case 3 (KM). Fundus photograph left posterior fundus taken 48 hours post-accident. There are multiple peripapillary cotton wool spots, intraretinal haemorrhage and macular oedema.

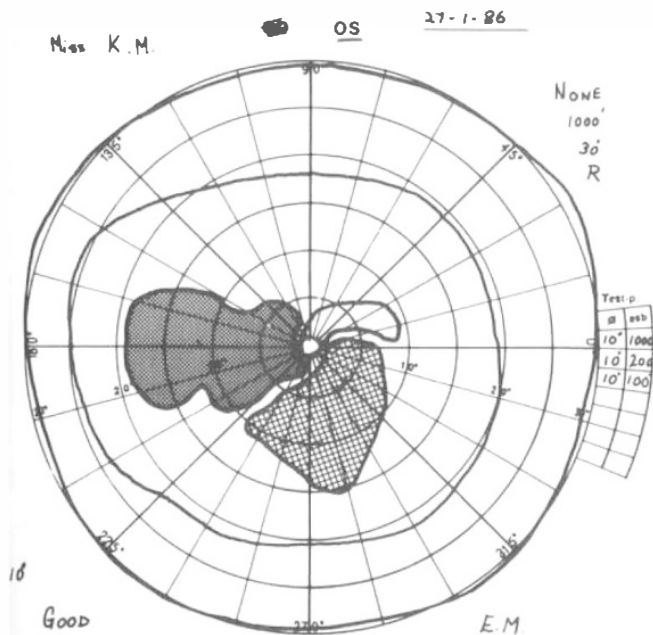

Fig. 5a. Case $3(K M)$. Left central vision field flat, $81 / 2$ years following road traffic accident. Dense paracentral scotomata are present. cal injuries occurring remote from the eye. Purtscher, ${ }^{11}$ at the turn of the century, was the first to establish an aetiological link between head injury and retinal vasculopathy and in 1910 described an unusual retinopathy characterised by white oval spots and scattered intraretinal haemorrhages in patients who had suffered concussional head injuries. Two years later he reported 3 further cases

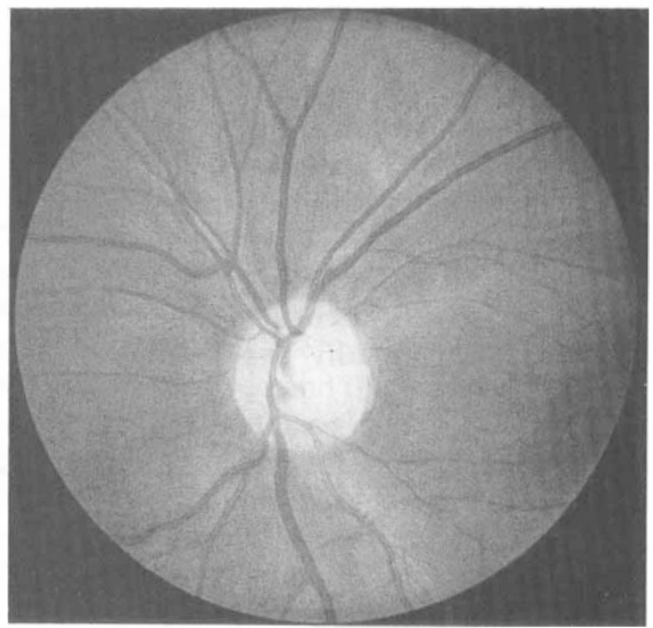

Fig. 4b. Case $3(K M)$. Left fundus photograph taken $81 / 2$ years after that shown in Fig. 4a. The optic disc is atrophic and some of the temporal arterioles are attenuated.

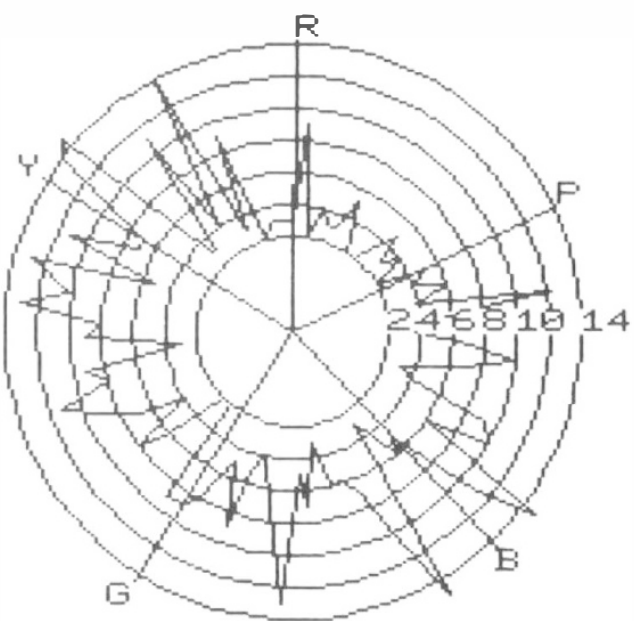

Fig. 5b. Farnsworth-Munsell 100 hue colour vision test $81 / 2$ years post road traffic accident. There is a striking red/green colour vision defect. 
and postulated that the white retinal spots were the result of an acute rise in cerebro-spinal fluid pressure and lymph stasis in the perivascular spaces of the retinal vessels. $\mathrm{He}$ labelled the condition "traumatic retinal angiopathy".

Since then unilateral or bilateral retinopathy similar to that described by Purtscher has been reported in patients with severe compressive chest injuries ${ }^{12}$ and after violent deceleration accidents. ${ }^{13} \mathrm{~A}$ similar fundus picture has also been described in conjunction with orbital and neck injuries, ${ }^{14}$ multiple bone fractures with evidence of fat embolism, ${ }^{15,16}$ and acute pancreatitis where complement induced leuko embolisation is held to be responsible for the retinal vasculopathy. ${ }^{17,18}$

The retinal vascular pathology in Purtscher's retinopathy has been variously attributed to a sudden rise in thoracic venous pressure, ${ }^{19}$ arterial angiospasm ${ }^{20,21}$ and occlusion of the retinal vessels by fat emboli, ${ }^{22}$, air $^{23}$ or aggregated granulocytes. ${ }^{17}$ In some patients with severe compressive head injuries there is widespread disruption of the ophthalmic carotid vasculatures resulting in generalised retinal and choroidal ischaemia. $^{24}$

Patients with seat belt-related retinopathy detailed in this report and published elsewhere $^{7,8,9}$ (Table III) form an unusual subclass of Purtscher's retinopathy with very similar clinical findings. Even though road traffic accidents are usually severe the systemic injuries sustained are often surprisingly slight in view of the profound alterations occurring in the retinal vasculature. The characteristic injuries are whiplash sprains of the neck and compression of the chest. None

Table III. Vehicle seat belt injuries with associated retinal angiopathy (Published cases)

\begin{tabular}{|c|c|c|c|c|c|c|c|c|c|}
\hline Author & Injury & $\begin{array}{l}\text { Visual } \\
\text { complaint }\end{array}$ & $\begin{array}{l}\text { Initial } \\
\text { acuity }\end{array}$ & $\begin{array}{l}\text { Final } \\
\text { acuity }\end{array}$ & $\begin{array}{l}\text { Initial } \\
\text { visual } \\
\text { field }\end{array}$ & $\begin{array}{l}\text { Final } \\
\text { visual } \\
\text { field }\end{array}$ & $\begin{array}{l}\text { Initial } \\
\text { fundus } \\
\text { changes }\end{array}$ & $\begin{array}{l}\text { Final } \\
\text { fundus } \\
\text { changes }\end{array}$ & $\begin{array}{l}\text { Time } \\
\text { follow } \\
\text { up }\end{array}$ \\
\hline $\begin{array}{l}\text { Hoare, } \\
\text { G.W. } \\
1970\end{array}$ & $\begin{array}{l}\text { Minor chest } \\
\text { compression }\end{array}$ & \multicolumn{2}{|c|}{$\begin{array}{l}\text { Blurred vision, CF } 6 / 60 \\
\text { central blind } \\
\text { spots R \& L, } \\
\text { few hours } \\
\text { post accident }\end{array}$} & $6 / 126 / 6$ & $\begin{array}{l}\text { Central } \\
\text { scotomata } \\
\mathrm{R} \& \mathrm{~L}\end{array}$ & $\begin{array}{l}\text { Small } \\
\text { paracentral } \\
\text { scotomata } \\
\text { R \& L }\end{array}$ & $\begin{array}{l}\text { Bilateral } \\
\text { peripapillary } \\
\& \text { macular } \\
\text { haemorrhage, } \\
\text { exudates and } \\
\text { oedema }\end{array}$ & $\begin{array}{l}\text { Not } \\
\text { recorded }\end{array}$ & $6 \mathrm{mths}$ \\
\hline $\begin{array}{l}\text { Kelley, } \\
\text { J.S. } \\
1972\end{array}$ & $\begin{array}{l}\text { Minor chest } \\
\text { compression }\end{array}$ & $\begin{array}{l}\text { Diminished } \\
\text { vision-R, } \\
\text { few mins } \\
\text { post accident }\end{array}$ & $\begin{array}{r}20 / 400 \\
20 / 20\end{array}$ & $\begin{array}{l}20 / 20 \\
20 / 20\end{array}$ & $\begin{array}{l}R \text {-small } \\
\text { central } \\
\text { scotoma }\end{array}$ & Normal & $\begin{array}{l}\text { R peri- } \\
\text { papillary } \\
\text { exudates, } \\
\text { macular } \\
\text { haemorrhages } \\
\& \text { oedema. } \\
\text { Arteriolar \& } \\
\text { Cap. leakage } \\
L \text { focal } \\
\text { vascular } \\
\text { leakage } \\
\text { Fl. Angio. } \\
\text { only }\end{array}$ & Normal & $10 \mathrm{wks}$ \\
\hline $\begin{array}{l}\text { Beckinsa } \\
\text { Rosenth } \\
1983\end{array}$ & $\begin{array}{l}\text { Minor whip } \\
\text { lash injury } \\
\text { head }\end{array}$ & \multicolumn{2}{|c|}{$\begin{array}{l}\text { Deterioration } 6 / 906 / 120 \\
\text { vision R \& L, } \\
5 \text { mins } \\
\text { post accident }\end{array}$} & $\begin{array}{l}6 / 7.56 / 6 \\
\text { one week } \\
\text { post } \\
\text { accident }\end{array}$ & $\begin{array}{l}\text { Dense } \\
\text { central } \\
\text { scotomata }\end{array}$ & $\begin{array}{l}\text { Bilateral } \\
\text { ring } \\
\text { scotomata }\end{array}$ & $\begin{array}{l}\text { Marked } \\
\text { retinal } \\
\text { oedema R \& L, } \\
\text { arteriolar } \\
\text { leakage } \\
\text { Fl. Angio. }\end{array}$ & $\begin{array}{l}\text { Fine } \\
\text { macular } \\
\text { pigmentation, } \\
\text { retinal } \\
\text { thinning }\end{array}$ & 6 months \\
\hline
\end{tabular}


of the patients described in this study or reported elsewhere suffered loss of consciousness, head injuries, long bone fractures or internal lesions that might be associated with classical Purtscher retinopathy.

The time of onset of visual symptoms following seat belt trauma is very variable, ranging from a few minutes to 48 hours. Patients with bilateral retinopathy report visual symptoms much earlier than those with unilateral changes. It may be that the retina can withstand the acute insult to its vasculature for a short period of time before vascular stasis and intraretinal oedema seriously interfere with neurotransmission, neuroconduction and vision. Alternatively, patients with mild or unilateral retinopathy may overlook or ignore their visual symptoms for some time due to shock, the presence of other injuries or distractions surrounding the accident. Most patients with seat belt-related retinal angiopathy have serious loss of vision in one or both eyes; 7 of 10 eyes reported to date in patients with seat belt retinopathy have had initial acuities of $6 / 60$ or less. There is no obvious correlation between the severity of chest or neck injuries and the degree of visual loss or any indication as to why the retinopathy is unilateral or bilateral. The extent of visual loss, however, closely parallels the degree of involvement of the macular arterioles in the disease process, the severity of retinopathy and the presence of macular oedema.

The other consistent changes in visual function are red/green or generalised colour vision defects, loss of contrast sensitivity and characteristic paracentral or ring scotomata. Most patients in this study and those described elsewhere show a slow return of visual functions with acuity and visual fields stabilising by 6 months post injury. All affected eyes in this study had permanent paracentral scotomata, impaired colour vision and diminished contrast sensitivity and had abnormalities of visually evoked responses, particularly the patterned reversal binary stimulus visually evoked response, which proved a very sensitive marker of traumatic retinopathy. All patients were acutely aware of a difference in the quality of vision between the 2 eyes and experienced some difficulty with tasks requiring stereopsis.

The initial retinopathy in this series and in other reported cases is confined to the posterior pole of the eye and characterised by retinal haemorrhages, peripapillary cotton wool spots and varying degrees of macular oedema and ischaemia. Fluorescein angiographic studies immediately post-injury show widespread impairment of retinal vascular perfusion with the most striking alterations at the level of the precapillary arterioles. The affected arterioles are typically dilated and incompetent and the downstream microvasculature is slowly and irregularly perfused..$^{8,9}$ These changes are almost identical to those occurring with head injuries and probably have a common pathogenesis. ${ }^{24}$

In this study the traumatic angiopathy had largely resolved and the affected microvasculature regained competence by 4 to 6 months. Nevertheless, residual microvascular abnormalities could always be discerned on detailed ophthalmoscopy or fluoroscein angiography, and nerve fibre bundle excavations, optic atrophy and afferent pupillary defects were present where retinopathy was severe and visual functions markedly depressed.

Two patients in this series demonstrated a striking alteration in retinal haemodynamics even at one year post accident. In one patient vascular stasis was so pronounced that "core" arterial filling could be followed through several sequential angiographic frames. Such arterial stasis suggests either a pronounced rise in the peripheral resistance of the retinal microvasculature subsequent to capillary loss or arteriolar damage, or alternatively a severe obstructive lesion at the level of the central retinal artery. It is unlikely that the ophthalmic artery was significantly involved in these patients as choroidal vascular perfusion was always normal and the ocular pulses were full and equal in both eyes.

The precise aetiology of this Purtscher-like retinopathy remains unclear, although the principal clinical feature is retinal arterial insufficiency, and most of the long term sequelae can be explained on the basis of inner retinal ischaemia and patchy loss of retinal ganglion cells and neurones. The 
acute arteriolar changes might be explained on the basis of a precipitate and momentary interruption of blood flow to the eye, perhaps induced by either acute neck flexion or sudden movements of the head causing direct injury to the carotoid/ophthalmic artery complex and spasm within the retinal vascular tree. It may also be that the traumatic angiopathy is triggered by acute chest compression, particularly against a closed glottis, causing a high venous pressure wave to be transmitted to the eye. This would be facilitated by the virtual absence of valves between the superior vena cava and the eye and influenced by factors such as neck position and the anatomical distribution of the cervical veins. These various factors could explain why this seat belt related retinopathy only affects some patients and why it is often a unilateral or asymmetrical event. $^{8}$ It may also be that the retinal vasculature which is devoid of any automatic control has no mechanism to resist or oppose such an acute elevation in venous pressure, and the subsequent precipitate rise in capillary pressure may induce precapillary arteriolar contraction by some, as yet undetermined, feedback mechanism. Beckinsale and Rosenthal ${ }^{8}$ believe that minor blows to the head or deceleration forces can cause considerable oscillatory movements within the vitreous body and produce substantial shearing forces between the vitreous and the retina. They postulate that such concussive forces can cause commotio retinae and account for some aspects of the traumatic angiopathy, particularly retinal oedema, annular scotomata and residual macular retinal pigment epithelial changes. One patient in our series had a slight disturbance of the macular retinal pigment epithelium; however, we believe these changes probably represent a response of the retinal pigment epithelium to retinal vascular stasis and intraretinal haemorrhage and fluid accumulation. ${ }^{25}$

We believe that a Purtscher-like retinopathy is probably not uncommon in patients sustaining seat belt injuries in road traffic accidents. The likely introduction of legislation requiring the use of rear seat belts and possible higher compliance rates in the future may well increase the incidence of traumatic retinal angiopathy in the future. In the acute stage the retinopathy is eminently recognisable if not pathognomonic; however, patients may not present for weeks or months after the accident when few observable fundus signs are present. In such patients the identification of a paracentral scotoma, colour vision defect or abnormal contrast sensitivity is strongly suggestive of a prior traumatic retinopathy and the presence of an abnormal patterned visually evoked response should confirm the diagnosis. Fluorescein angiography is particularly helpful in that it may demonstrate retinal vascular stasis and microvascular alterations many years after the original injury and serve as a useful longterm marker for traumatic retinal angiopathy. The identification of these specific changes. months or years after a severe chest, neck or head injury has important diagnostic and medico-legal implications.

\section{References}

${ }^{1}$ Rutherford WH, Greenfield AA, Hayes HRM, Nelson JK: The medical effects of seat belt legislation in the United Kingdom. Department of Health \& Social Security Office of the Chief Scientist. Research Report No. 13. London: HMSO 1985.

2 Johnston PB and Armstrong MJF: Eye injuries in Northern Ireland two years after seat belt legislation. Br J Ophthalmol, 1986; 70: 460-2.

${ }^{3}$ Trinca GW and Dooley BJ: Effects of seat belt legislation on road traffic accidents. Aust NZ J Surg, 1977, 47: 150-5.

${ }^{4}$ Hall NF, Denning AM, Elkington AR, Cooper PJ: The eye and the seat belt in Wessex. $B r J$ Ophthalmol, 1985; 69: 317-9.

${ }^{5}$ Dajee $\mathrm{H}$ and MacDonald AC: Gastric rupture due to seat belt injury. Br J Surg, 1982; 69: 436-7.

${ }^{6}$ Denis $P$, Allard $M$, Atlas $H$, Farmouh E: Changing trends with abdominal injuries in seat belt wearers. J Trauma, 1983; 23: 1007-8.

${ }^{7}$ Hoare GW: Traumatic retinal angiopathy resulting from chest compression by safety belt. Br J Ophthalmol, 1970; 54: 667-9.

${ }^{8}$ Beckinsale AB and Rosenthal AR: Early fundus fluorescein angiographic findings and sequelae in traumatic retinopathy: Case report. Br J Ophthalmol, 1983; 67: 119-23.

${ }^{9}$ Kelley JS: Purtscher's retinopathy related to 
chest compression by safety belts: Fluorescein angiographic findings. Am J Ophthalmol, 1972, 74: 278-83.

${ }^{10}$ Srebro R and Wright WW: Visually evoked potential to pseudorandom binary stimulation. Preliminary clinical trials. Arch Ophthalmol, 1980; 98: 296-8.

${ }_{11}$ Purtscher O: Noch unbekannte Befunde nach Schadeltrauma. Ber Versamml Deutschen Ophthalmol. Gesell, 1910; 36: 292-307.

12 Teichmann KD and Gronemeyer U: Unilateral morbus Purtscher with poor visual outcome. Ann Ophthalmol, 1981; 13: 1295-99.

${ }^{13}$ Lyle DJ, Stapp JP, Button RR: Ophthalmological hydrostatic pressure syndrome. Am J Ophthalmol, 1957; 44: 6527.

${ }^{14}$ Madsen PH: Traumatic retinal angiopathy. Acta Ophthalmol, 1965; 43: 776-86.

15 Urbanek J: Uber Fettembolie des Auges. Albrecht von Graefes Arch Ophthalmol, 1934; 131: $147-73$

16 Yanagisawa Y, Iwata T, Murase I, Tsurimaki Y: Ophthalmological findings in five cases of systemic fat embolism syndrome. Folio Ophthalmol Jpn, 1985; 36: 590-5.

17 Jacob HS, Goldstein IM, Shapiro I, Craddock PR, Hammerschmidt DE, Weissman G:
Sudden blindness in acute pancreatitis. Possible role of complement-induced retinal leukoembolization. Arch Intern Med, 1981; 141: $134-6$.

${ }^{18}$ Inkeles DM, Walsh JH, Matz R: Purtscher's retinopathy in acute pancreatitis. $\mathrm{Am} \mathrm{J} \mathrm{Med}$ Scl, 1976; 272: 335-8.

${ }^{19}$ Marr WG and Marr EG: Some observations on Purtscher's disease: traumatic retinal angiopathy. Am J Ophthalmol, 1962; 54: 693.

${ }^{20}$ Anderson WC: Purtscher's retinopathy. Am J Ophthalmol, 1951; 34: 1114.

${ }^{21}$ Frandsen E: Purtscher's disease. Nord Med, 1956, 56: $1097-8$.

${ }^{22}$ Kearns TP: Fat embolism of the retina. Demonstration by a flat retinal preparation. Am J Ophthalmol, 1956; 41: 1-2.

${ }^{23}$ Burton TC: Unilateral Purtscher's retinopathy. Ophthalmology, 1980; 87: 1096-1105.

${ }^{24}$ Archer DB, Earley OE, Page AB, Johnston PB: Retinal vascular alterations following head injury. Proceedings of the Retina Workshop Florence, Italy, May 1986; pp 105112.

${ }^{25}$ Archer DB and Gardiner TA: Experimental inner retinal ischaemia and the blood retinal barriers. In The Blood Retinal Barriers. Ed JG Cunha-Vaz. Plenum Pub; pp 279-99. 